\title{
Biosintesis Nanopartikel Fe dari Pasir Besi Menggunakan Ekstrak Kulit Bawang Merah
}

\author{
Susi Dianti, Agrippina Wiraningtyas, Ruslan* dan Sry Agustina
}

Email: ruslanabinada@gmail.com

\begin{abstract}
ABSTRAK
Penelitian bertujuan untuk melakukan sintesis nanopartikel Fe (Besi) dari pasir besi menggunakan ekstrak kulit bawang merah. Kulit bawang merah segar dicuci dan dikeringkan, setelah itu kulit bawang merah yang sudah kering kemudian dihaluskan (diblender) terbentuk serbuk kulit bawang merah dan dimaserasi dengan menggunakan pelarut etanol 96\% selama 1 jam, selanjutnya di saring dengan menggunakan kertas saring untuk mendapatkan ekstrak kulit bawang merah. sintesis besi Oksida dengan metode pelarutan bubuk pasir besi dalam larutan HCl pekat. Larutan yang dihasilkan selanjutnya dicampur dengan ekstrak kulit bawang merah sebagai bioreduktor disintesis selama 10, 20, 30, 40 menit kemudian diamati perubahan warnanya dan terbentuknya nanopartikel Fe jika terjadi perubahan warna. sampel dilakukan uji menggunakan alat spektrofotometer UV-Vis. Berdasarkan hasil penelitian Nanopartikel Fe dapat dibuat dari pasir besi menggunakan ekstrak kulit bawang merah, ditunjukan dengan adanya perubahan warna dari larutan tersebut dan adanya perbedaan nilai absorbansi. Waktu optimum biosintesis nanopartikel Fe dari pasir besi menggunakan ekstrak kulit bawang merah dengan spektrofotometer UV-Vis yaitu pada saat pengadukan 10 menit dengan nilai absorbansi tertinggi 4.532 pada panjang gelombang $215 \mathrm{~nm}$.
\end{abstract}

Kata Kunci : Biosintesis, Nanopartikel Fe, pasir besi, kulit bawang merah

\section{PENDAHULUAN}

Industri di Indonesia sudah berkembang luas, bahkan industri konvensional juga jumlahnya semakin banyak. Seiring perkembangan tersebut masalah limbah industri pun semakin banyak sehingga sangat berpengaruh terhadap lingkungan. Sebagai contohnya limbah industri tahu dan tempe yang dapat menimbulkan bau menyengat dan polusi berat. Sangat sulit bagi industri-industri ini untuk meremediasi lingkungannya dikarenakan teknik dan alatnya yang cukup mahal. Salah satu potensi yg dimiliki Indonesia yang dapat memberikan solusi terhadap hal tersebut yaitu pasir besi. Pasir besi biasanya diolah untuk dimanfaatkan sebagai magnetik, namun selain itu pasir besi juga memiliki potensi sebagai nano material. Nano material salah satunya nanopartikel besi, dapat digunakan sebagai remediasi lingkungan yang tercemar oleh limbah polutan.

Nanopartikel Fe atau yang biasa dikenal dengan nano-scaled zero valensi iron (nZVI), merupakan nanopartikel yang unggul dalam proses remediasi lingkungan. Dibandingkan dengan partikel zero valensi iron (ZVI) yang berukuran besar (bulk), nZVI mempunyai reaktifitas yang lebih tinggi karena memiliki luas permukaan yang besar. Beberapa studi telah menunjukan potensi nanopartikel Fe untuk remediasi lingkungan, diantaranya yang dilakukan oleh Shahwan dkk, yang menggunakan nanopartikel Fe untuk mendegradasi polutan organik dan anorganik. Untuk mendapatkan nanopartikel Fe pada penelitian ini yaitu dengan metode biosintesis (Ruslan dan Ariyansyah, 2019).

Biosintesis nanopartikel merupakan sintesis nanopartikel dengan memanfaatkan makhluk hidup sebagai agen biologi pada proses sintesisnya. Penggunaan agen biologi dalam proses sintesis ialah dengan memanfaatkan senyawa-senyawa organik yang 
terkandung dalam makhluk hidup. Agen biologi berperan sebagai pereduksi, penstabil, atau keduanya pada proses pembentukan nanopartikel. Menurut beberapa penelitian, telah mengungkapkan bahwa molekul bioaktif yang kemungkinan besar berperan sebagai agen pereduksi dan penstabil dalam proses biosintesis nanopartikel yaitu protein, polisakarida, tanin, flavonoid, terpenoid (Mittal dkk, 2013). Prinsip biosintesis dengan metode green synthesis (sintesis hijau) dengan menggunakan ekstrak tumbuhan (Ahmad dkk, 2003). Pendekatan sintesis hijau memberikan perkembangan yang jauh lebih baik karena dilakukan pada tekanan dan suhu kamar, ekonomis, serta bebas dari penggunaan bahan kimia beracun (Rajeshkumar dkk, 2012). Ekstrak tumbuhan, jamur, ragi, bakteri, virus, dan alga yang berpotensi sebagai media sintesis nanopartikel (Seabra dkk, 2013). Salah satu metode biosintesis menggunakan ekstrak kulit bawang merah.

Limbah kulit bawang merah (Allium ascalonicum L.) yang dihasilkan dari industri rumah tangga sebagian besar belum bisa dimanfaatkan. Hal ini sangat disayangkan karena di dalam kulit bawang merah ini ternyata mengandung banyak sekali senyawa-senyawa kimia yang bisa dimanfaatkan, salah satunya adalah senyawa flavonoid (Siti, 2015; Ruslan $\mathrm{dkk}$, 2019) yang kemungkinan besar dapat berpotensi sebagai agen pereduksi dan penstabil dalam proses biosintesis nanopartikel. Berdasarkan latar belakang masalah di atas maka perlu dilakukan penelitian tentang biosintesis nanopartikel Fe (Besi) dari pasir besi menggunakan ekstrak kulit bawang merah.

\section{METODE}

\section{Alat dan Bahan Penelitian}

Adapun alat dan bahan yang digunakan dalam penelitian ini adalah sebagai berikut: Alat yang digunakan dalam penelitian ini adalah: magnet, gelas ukur, erlenmeyer, gelas kimia, tabung reaksi, rak tabung reaksi, blender, corong, neraca analitik, gunting, pengaduk, pipet tetes dan serangkaian alat analisa spektrofotometer UV-Vis. Bahan yang digunakan dalam penelitian ini adalah: pasir besi, kulit bawang merah, aquades, alkohol 96\%, kertas saring whatman, alumium foil, $\mathrm{HCl}$ pekat, dan kertas label.

\section{Prosedur Penelitian}

Adapun prosedur penelitian terdiri dari: preparasi sampel, ekstraksi dengan menggunakan metode maserasi, dan analisis stabilitas zat warna.

\section{Pengambilan Sampel}

Tahap ini, pasir di pantai Oi Tui diambil pasir besinya, kemudian pasir besi yang diperoleh dioven dengan temperatur $80^{\circ} \mathrm{C}$ selama $1 / 2$ jam guna mengurangi kadar air pada pasir besi setelah itu dibersihkan dari pengotornya dengan menggunakan magnet eksternal. Padatan yang tertarik oleh magnet lalu digerus.

\section{Pembuatan Ekstrak Kulit Bawang Merah}

Kulit bawang merah segar dicuci dan dikeringkan, setelah itu kulit bawang merah yang sudah kering kemudian dihaluskan (diblender) terbentuk serbuk kulit bawang merah dan dimaserasi dengan menggunakan pelarut etanol 96\% selama 1 jam, selanjutnya di saring dengan menggunakan kertas saring untuk mendapatkan ekstrak kulit bawang merah. 


\section{Sintesis Nanopartikel Fe}

Tahap ini yaitu sintesis besi Oksida dengan metode pelarutan bubuk pasir besi dalam larutan $\mathrm{HCl}$ pekat sesuai dengan reaksi berikut.

$$
\text { Reaksi: } \mathrm{HCl}+\mathrm{Fe}_{3} \mathrm{O}_{2} \longrightarrow \mathrm{Fe}^{3+}+\mathrm{Cl}^{-}+\mathrm{H}_{2} \mathrm{O}
$$

Larutan yang dihasilkan selanjutnya dicampur dengan ekstrak kulit bawang merah sebagai bioreduktor disintesis selama 10, 20, 30, 40 menit kemudian diamati perubahan warnanya dan terbentuknya nanopartikel Fe jika terjadi perubahan warna. Variabel yang diteliti dalam penelitian ini yaitu variasi lama waktu pengadukan larutan sampel yaitu 10; 20; 30 dan 40 menit.

\section{Analisis Sampel}

Setelah rangkaian tahap dilakukan, terakhir, sampel dilakukan uji menggunakan alat spektrofotometer UV-Vis.

\section{HASIL DAN PEMBAHASAN Preparasi Sampel}

Pasir besi dicuci untuk menghilangkan kandungan garamnya, lalu dioven pada suhu $80^{\circ} \mathrm{C}$ selama $1 / 2$ jam untuk mengurangi kadar air pada pasir tersebut. Kemudian dibersihkan yang bertujuan untuk memisahkan pasir besi dengan pengotornya lalu digerus agar mendapatkan ukuran yang lebih kecil karena semakin kecil ukuran suatu sampel maka semakin luas permukaan sampel tersebut. sehingga efektif ketika perendaman berlangsung. Untuk memperoleh ion $\mathrm{Fe}^{3+}$ dari senyawa $\mathrm{Fe}_{3} \mathrm{O}_{2}$ (pasir besi) dilakukan perendaman pasir besi ke dalam $100 \mathrm{ml}$ larutan $\mathrm{HCl}$ pekat, sehingga dihasilkan larutan ion $\mathrm{Fe}^{3+}$ yang berwarna kuning pekat. Reaksi yang terjadi dan proses pembuatan larutan seperti pada gambar 1.

$$
\mathrm{HCl}+\mathrm{Fe}_{3} \mathrm{O}_{2} \longrightarrow \mathrm{Fe}^{3+}+\mathrm{Cl}^{-}+\mathrm{H}_{2} \mathrm{O}
$$

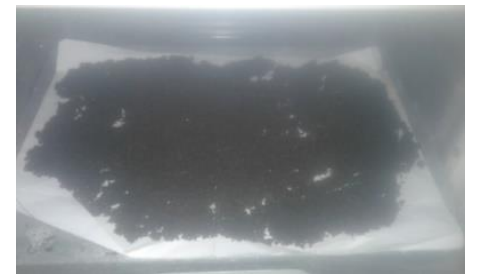

Pengeringan sampel

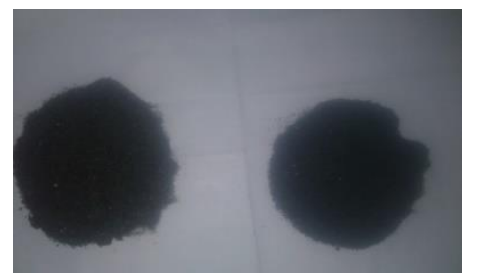

Sampel siap pakai (kanan); sampel sebelum dipreparasi (kiri)

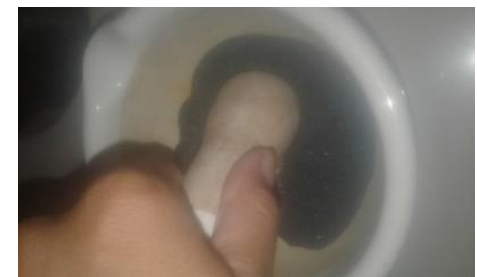

penggerusan sampel

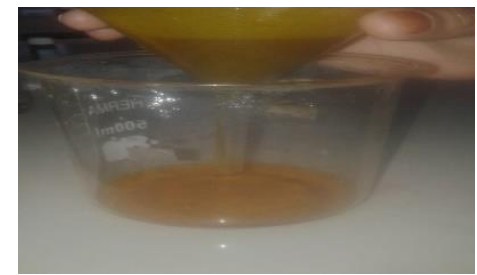

larutan $\mathrm{Fe}^{3+}$

\section{Gambar 1. Preparasi Sampel}

\section{Preparasi Bioreduktor}

Kulit bawang merah dicuci bersih kemudian dikeringkan untuk mengurangi kadar air yang terkandung di dalamnya. Pengeringan juga bertujuan agar kadar air dalam sampel 
tidak mengganggu hasil ekstrak yang didapatkan. Selanjutnya dihaluskan dengan tujuan untuk memperluas permukaan kulit bawang merah sehingga ekstrak yang didapat semakin banyak/maksimal. Metode ekstraksi yang digunakan adalah maserasi dengan pelarut etanol 96\% selama 1 jam sambil diaduk. Terakhir, dipisahkan antara filtrat dengan residu dengan menyaring dengan menggunakan kertas saring.

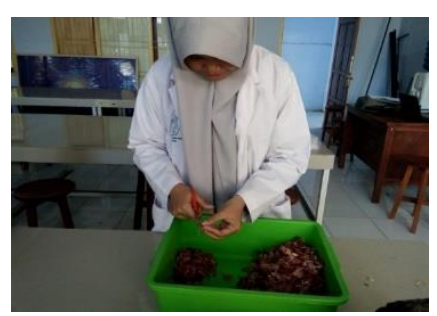

Pemotongan KBM

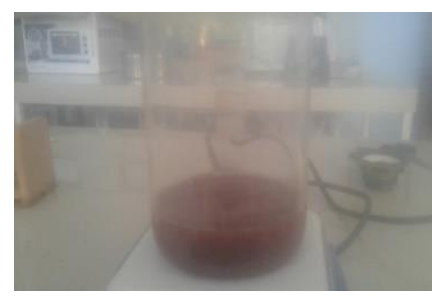

Proses ekstraksi

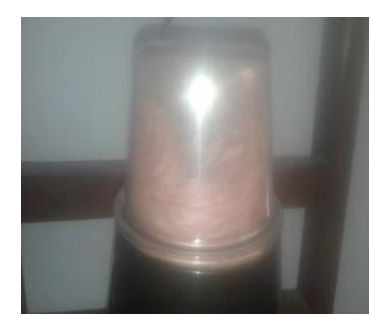

Penghalusan

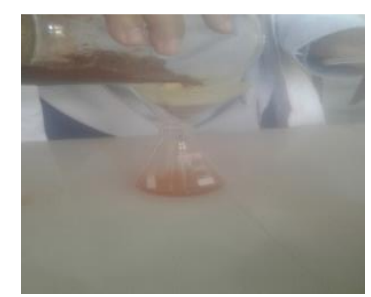

Proses penyaringan

Gambar 2. Preparasi Bioreduktor

\section{Penentuan Nilai Absorbansi sampel}

Hasil pengukuran dengan alat Spektrofotometer UV-Vis dengan rentang panjang gelombang 200-500 nm pada ion $\mathrm{Fe}^{3+}$ menunjukan bahwa adanya puncak serapan dengan nilai absorbansi $=3.459$ pada panjang gelombang $244 \mathrm{~nm}$. Sedangkan pada ekstrak kulit bawang merah menunjukan bahwa terbentuk puncak serapan dengan nilai absorbansi = 3.521 pada panjang gelombang $215 \mathrm{~nm}$ seperti ditunjukkan pada gambar 2. Adanya serapan karena kedua larutan tersebut berwarna sehingga memiliki nilai absorbansi (Ismaya, 2017).

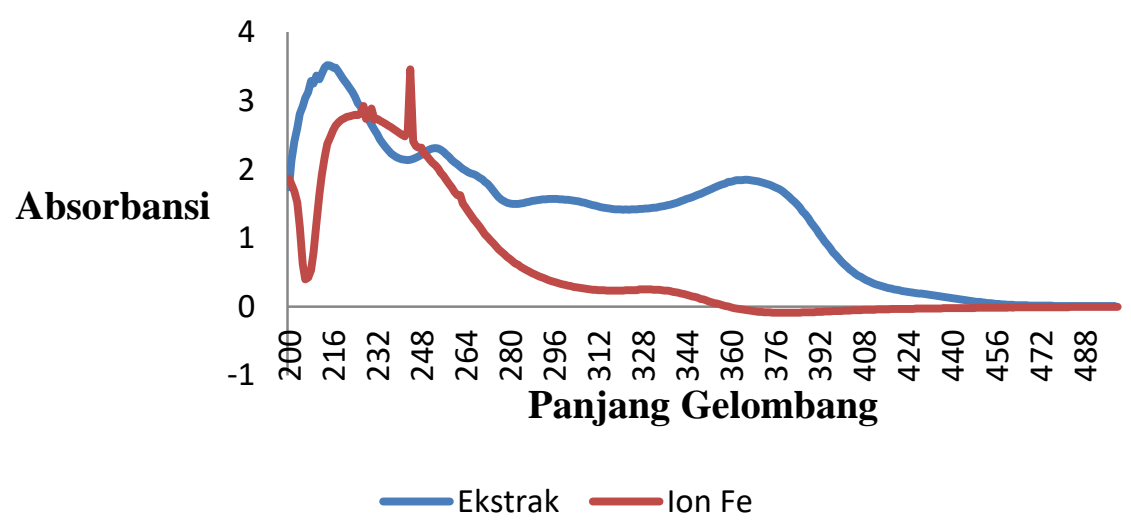

Gambar 3. Grafik UV Vis ekstrak kulit bawang merah dan lar. Ion $\mathrm{Fe}^{3+}$ 


\section{Biosintesis Nanopartikel Fe}

Biosintesis nanopartikel dilakukan dengan bahan alam seperti ekstrak tanaman sebagai zat pereduksi (penurunan bilangan oksidasi). Metode ini bertujuan agar proses pembentukan nanopartikel lebih ramah lingkungan dan tidak membutuhkan banyak bahan kimia (Elumalai, 2011). Proses reduksi $\mathrm{Fe}^{3+}$ menjadi $\mathrm{Fe}^{\circ}$ tidak lepas dari peran senyawa tertentu yang bersifat bioreduktor. Terbentuknya nanopartikel Fe dapat dilihat pada perubahan warna larutan dapat dilihat dari gambar 4.

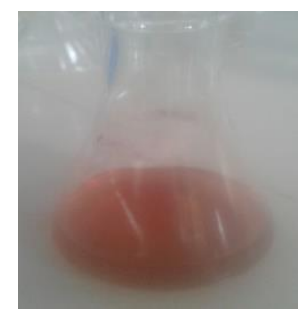

Ekstrak

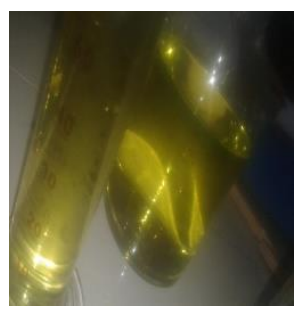

Larutan ion $\mathrm{Fe}^{3+}$

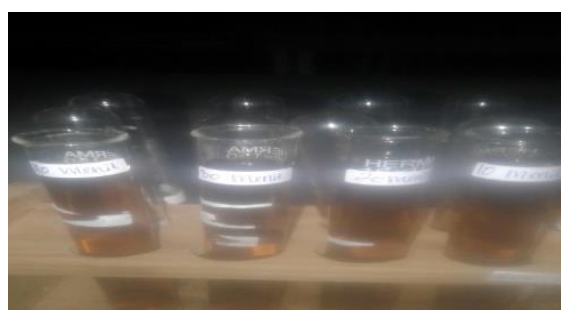

Larutan nanopartikel Fe

Gambar 4. Biosintesis Nanopartikel Fe dari Pasir Besi

Salah satu indikator terbentuknya nanopartikel pada larutan yaitu ditandai dengan adanya perubahan warna pada larutan tersebut. Larutan campuran yang terdiri dari ekstrak kulit bawang merah dengan ion $\mathrm{Fe}^{3+}$ terjadi perubahan warna setelah pencampuran seperti yang terlihat pada gambar di atas.

Pada proses sintesis nanopartikel besi dengan menggunakan ekstrak kulit bawang merah ini teramati perubahan warna larutan dari coklat muda menjadi coklat pekat. Perubahan warna tersebut adalah salah satu indikator terbentuknya nanopartikel (Priya, 2012). Nanopartikel besi ini dapat terbentuk karena di dalam ekstrak kulit bawang merah ini terdapat senyawa kimia yaitu flavonoid. Flavonoid yang terkandung yang menjadi bioreduktor karena senyawa tersebut memiliki gugus $-\mathrm{OH}$ yang mampu untuk mendonorkan proton. Ekstrak Fitoplankton $S$. platensis dicampur dengan larutan $\mathrm{FeCl}_{3}$ dan ion $\mathrm{Fe}^{3+}$ tereduksi menjadi $\mathrm{Fe}^{0}$ yang diamati dengan mengukur spektrum UV-Vis dari media reaksi.

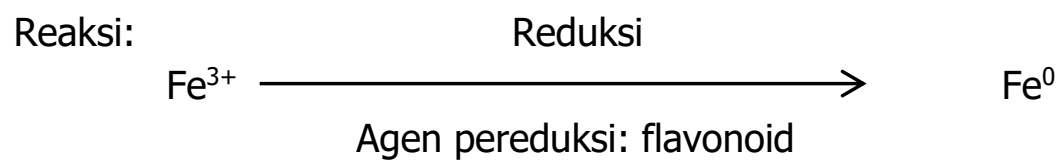

Absorbansi semakin besar seiring bertambahnya waktu pengadukan. Besarnya nilai absorbansi berhubungan dengan nanopartikel yang terbentuk, sehingga dapat disimpulkan bahwa proses reaksi pembentukan nanopartikel besi menggunakan ekstrak kulit bawang merah mempunyai orde menit. 


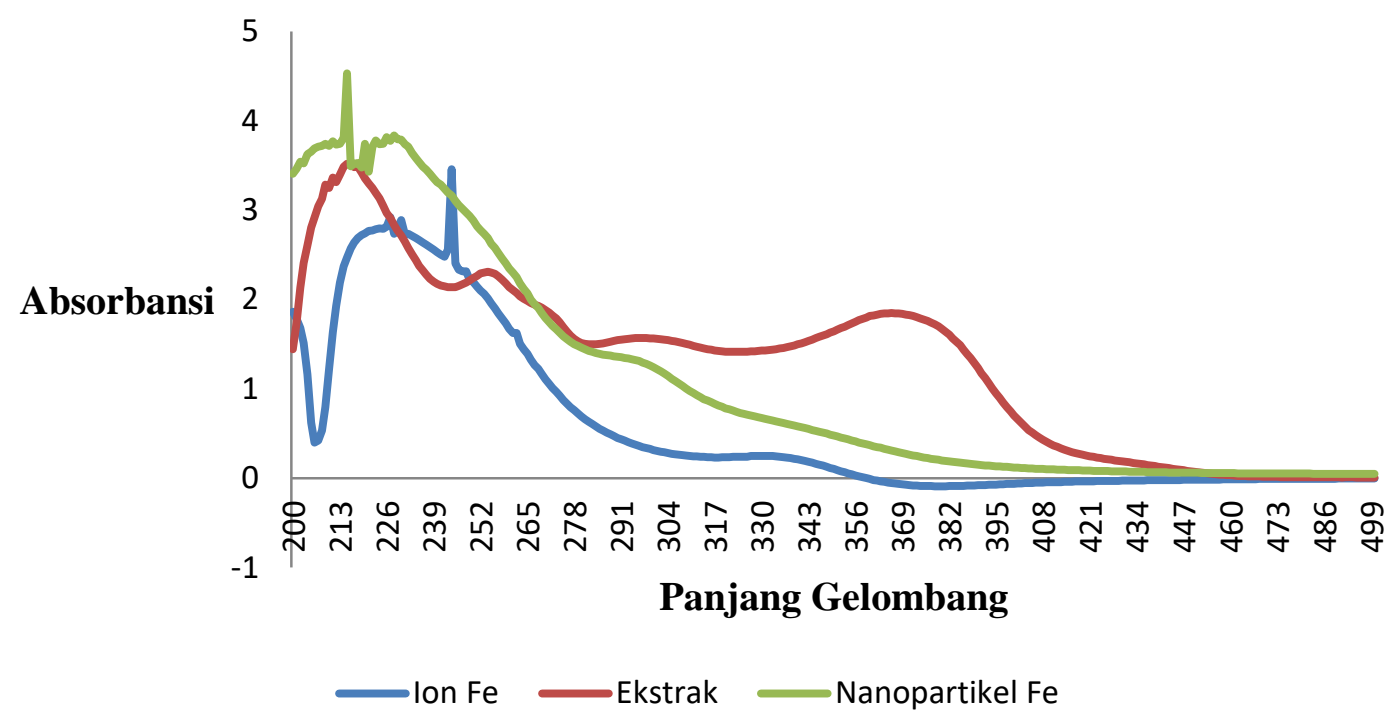

Gambar 5. Grafik UV Vis Nanopartikel Fe

Gambar di atas menunjukan bahwa spektrum ekstrak kulit bawang merah terjadi pada serapan panjang gelombang $3.521 \mathrm{~nm}$. Setelah ekstrak direaksikan dengan ion $\mathrm{Fe}^{3+}$, pembentukan nanopartikel Fe diamati terjadi pada penyerapan panjang gelombang sebesar $215 \mathrm{~nm}$ dengan nilai absorbansi yang lebih tinggi setelah 10 menit pencampuran. Dilihat dari gambar di atas bahwa data absorbansi antara larutan Ion $\mathrm{Fe}^{3+}$, ekstrak kulit bawang merah hingga terbentuknya nanopartikel Fe maka nilai absorbansi yang didapatkan semakin tinggi, dengan adanya perubahan nilai absorbansi yang didapatkan dan semakin tingginya nilai absorbansi maka menunjukan terbentuknya nanopartikel Fe.

\section{Variasi Waktu sintesis}

Larutan yang sintesis yang merupakan campuran dari larutan ion $\mathrm{Fe}^{3+}$ dengan larutan ekstrak kulit bawang merah kemudian diaduk dengan variasi pengadukan 10 menit, 20 menit, 30 menit, dan 40 menit, kemudian diukur nilai asorbansinya menggunakan spektrofotometer UV-Vis. Nilai absorbansi nanopartikel Fe yang terbentuk pada variasi waktu sintesis seperti pada tabel 1.

Tabel 1. Absorbansi nanopartikel Fe pada Variasi Waktu sintesis

\begin{tabular}{|llll|}
\hline No & $\begin{array}{l}\text { Waktu Sintesis } \\
\text { (Menit) }\end{array}$ & $\begin{array}{l}\text { Panjang gelombang } \\
\text { (nm) }\end{array}$ & Absorbansi \\
\hline 1 & 10 & 215 & 4.532 \\
\hline 2 & 20 & 215 & 3.482 \\
\hline 3 & 30 & 203 & 3.308 \\
\hline 4 & 40 & 220 & 3.928 \\
\hline
\end{tabular}

Dalam penelitian ini, eksperimen untuk mengetahui pengaruh pengadukan terhadap nanopartikel yang dihasilkan dilakukan dengan cara mengaduk larutan biosintesis selama 10 menit, 20 menit, 30 menit, dan 40 menit. Proses pencampuran antara larutan ion besi 
dengan larutan ekstrak kulit bawang merah dilakukan dengan menuangkannya secara bersamaan ke dalam wadah (gelas kimia).

Larutan Fe yang diperoleh selanjutnya diukur nilai absorbansinya menggunakan spektrofotometer UV-Vis. Adapun alat Spektrofotometer UV-Vis yang digunakan pada penelitian ini yaitu tipe GENESYS 10S UV-Vis v4.006 2L5V282308. Menurut (Nurlaila, 2016) daerah panjang gelombang untuk mengukur absorbansi nanopartikel Fe yaitu antara 300$700 \mathrm{~nm}$. Akan tetapi, pada penelitian ini daerah panjang gelombang yang digunakan yaitu rentang antara 200-500 nm. Hal ini dilakukan karena batas bawah panjang gelombang yang dapat terbaca oleh double-beam instrument adalah $190 \mathrm{~nm}$. Sedangkan, batas atas (maksimum) pada rentang panjang gelombang tersebut dipilih $500 \mathrm{~nm}$, karena pada panjang gelombang $400 \mathrm{~nm}$ adalah batas maksimum senyawa organik dapat menyerap sinar UV agar absorbansinya dapat terbaca, serta batas minimum senyawa organik dapat menyerap sinar tampak agar absorbansinya dapat terbaca (Suharti, 2017). Berdasarkan hasil pengukuran yang dilakukan menunjukkan bahwa spektrum terjadi pada penyerapan panjang gelombang sebesar $215 \mathrm{~nm}$ dengan nilai absorbansi yang lebih tinggi setelah 10 menit pengadukan. Berikut gambar perubahan nilai absorbansi yang signifikan dari perbedaan variasi waktu pengadukan larutan sintesis (Elumalai, 2011).

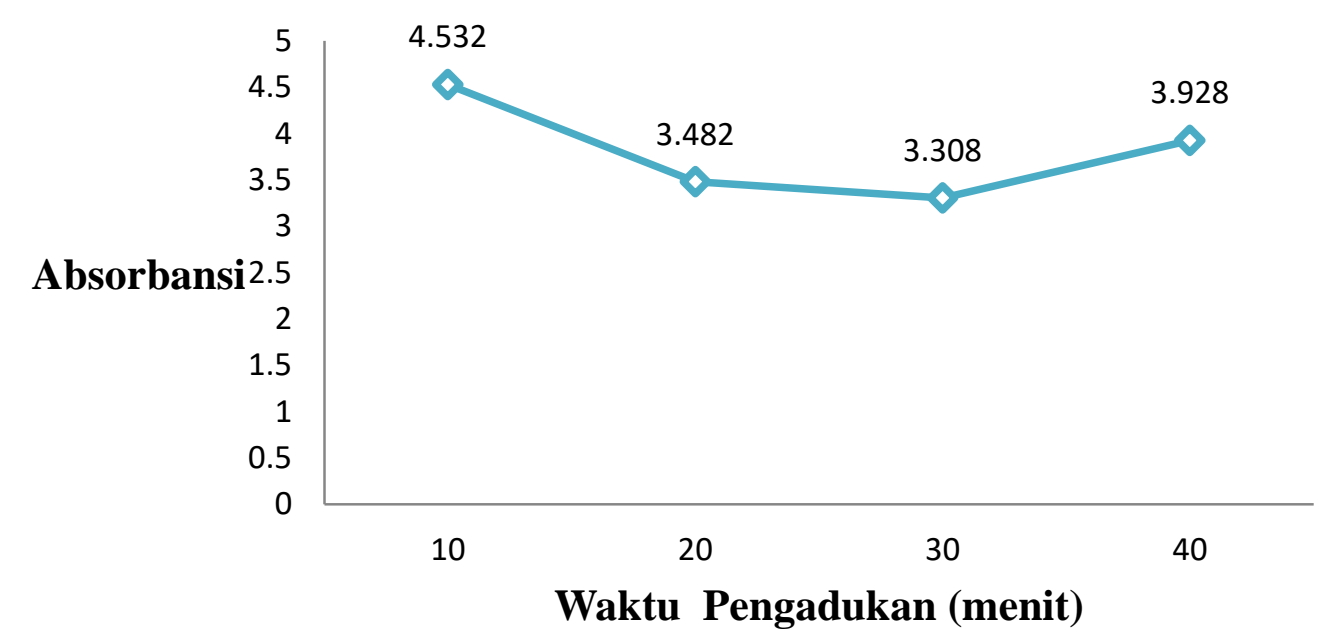

Gambar 6. Nilai absorbansi nanopartikel Fe terhadap waktu sintesis

Berdasarkan grafik pada gambar 6 di atas, nilai absorbansi larutan dari 10-20 menit terjadi pergeseran panjang gelombang dari 215-203 dan data absorbansinya mengalami penuruanan dikarenakan nanopartikel perak yang dihasilkan tidak mudah teroksidasi dan beraglomerasi membentuk ukuran yang lebih besar (Tikirik, 2013). Sedangkan pada waktu pengadukan 30-40 menit, nilai absorbansinya mengalami kenaikan itu itu menandakan nanopartiekl Fe yang terbentuk semakin banyak.

\section{KESIMPULAN}

Berdasarkan hasil penelitian Nanopartikel Fe dapat dibuat dari pasir besi menggunakan ekstrak kulit bawang merah, ditunjukan dengan adanya perubahan warna dari larutan tersebut dan adanya perbedaan nilai absorbansi. Waktu optimum biosintesis nanopartikel Fe dari pasir besi menggunakan ekstrak kulit bawang merah dengan 
spektrofotometer UV-Vis yaitu pada saat pengadukan 10 menit dengan nilai absorbansi tertinggi 4.532 pada panjang gelombang $215 \mathrm{~nm}$.

\section{UCAPAN TERIMAKASIH}

Penulis mengucapkan terimakasih kepada semua pihak yang telah membantu baik moril maupun materil dalam penyelesaian artikel ini.

\section{DAFTAR PUSTAKA}

Ahmad, A., Senapati, S., Islam Khan, M., Kumar, R., Sastry, M. 2003. Sintesis Nanopartikel Fe Menggunakan Bioreduktor Ekstrak Fitoplankton Spirulina Platensis. J. Chem. Res. Hal. 277-278.

Elumalai. 2011. Sintesis Nanopartikel Perak Menggunakan Bioreduktor Dari Ekstrak Kulit Buah Manggis (Garcinia mangostana L.) Sebagai Indikator Kolorimetri Keberadaan Logam Hg2+. Makasar. Universitas Hasanuddin. Hal. 215.

Ismaya. 2017. Sintesis Nanopartikel Perak Menggunakan Bioreduktor dari Ekstrak Kulit Buah Manggis (Garcinia mangostana L.) Seabagai Indikator Kalorimetri Keberadaan Logam $\mathrm{Hg}+$. Makasar. Universitas Hasannudin. Hal. 152.

Nurlaila, Isti. 2016. Sintesis Nanopartikel Fe Menggunakan Bioreduktor Ekstrak Fitoplankton Spirulina Platensis. J. Chem. Res. Hal. 279.

Mittal, A. K., Chisti, Y. dan Banerjee, U. C. 2013. Sintesis Nanopartikel Fe Menggunakan Bioreduktor Ekstrak Fitoplankton Spirulina Platensis. J. Chem. Res. Hal. 278.

Ruslan, R., Agustina, S., \& Hasanah, U. (2019). Penentuan Nilai Sun Protection Factor (SPF) dari Kulit Bawang Merah. JURNAL REDOKS: JURNAL PENDIDIKAN KIMIA DAN ILMU KIMIA, 2(01), 34-43.

Ruslan and Ariyansyah. 2019. Biosynthesis of Titanium dioxide using Sargassum sp. extrac under microwave. International Journal of Applied Chemistry. 15 (2), 113-120.

Seabra, A, B., Haddad, P., dan Duran, N. 2013. Sintesis Nanopartikel Fe Menggunakan Bioreduktor Ekstrak Fitoplankton Spirulina Platensis. J. Chem. Res. Hal. 278.

Siti. 2015. Ekstraksi dan Identifikasi Senyawa Flavonoid dari Limbah Kulit Bawang Merah sebagai Antioksidan Alami. Al Kimiya. Vol. 2. No. 1. Hal. 8.

Suharti. 2017. Green Synthesis Nanopartiekl Perak dari Limbah Forografi dengan Menggunakan Ekstrak Kulit Buah Naga. Yogyakarta. Universitas Islam Indonesia. Hal. 18.

Tikirik, W. O. 2013. Sintesis Nanopartikel Perak Menggunakan Bioreduktor Dari Ekstrak Kulit Buah Manggis (Garcinia mangostana L.) Sebagai Indikator Kolorimetri Keberadaan Logam Hg2+. Makasar. Universitas Hasanuddin. Hal. 105-106.

Yuli. 2016. Pemanfaatan Ekstrak Air Rimpang Jahe Merah (Zingiber officinale Linn var rubrum) pada Biosintesis Sederhana Nanopartiekel Perak . Chimica et Natura Acta. Vol. 4. No. 3. Hal. 151, 152, 153.

Yulia. 2010. Biosintesis Nanopartikel Perak Menggunakan Ekstrak Metanol Daun Manggis (Garcinia mangostana L.). Jurnal Chemica. Vol. 15. No. 2. Hal. 47. 